\title{
Bioefficacy and Phytotoxicity of Profenofos 50EC against Tea Red Spider Mite, Oligonychus coffeae (Nietner)
}

\author{
S. Rahman $^{1 *}$, D. Sharmah ${ }^{2}$, R. P. Bhuyan ${ }^{3}$ \\ ${ }^{1}$ Department of Entomology, AAU, Jorhat, Assam, India \\ ${ }^{2}$ Krishi Vigyan Kendra (ICAR), South Tripura, Tripura, India \\ ${ }^{3}$ Department of Tea Husbandry and Technology, AAU, Jorhat, Assam, India
}

\begin{abstract}
An experiment was conducted in the Experimental Garden for Plantation Crops, Assam Agricultural University, Jorhat during Kharif, 2013 and 2014 to evaluate the efficacy and phytotoxic effect of profenofos 50 EC, a new molecule of chemical pesticide against tea red spider mite, Oligonychus coffeae Nietner in comparison to the market samples of profenofos 50 EC. All the treatments were found to be significantly superior over control after $1^{\text {st }}$ spraying. Profenofos 50 EC @ 750, 1000 and 1000 (market sample) $g$ a.i./ha proved to be most effective treatment that gave 100 per cent reduction of mite population after one day of spraying. Reduction of mite population due to new molecule of profenofos 50 EC @ $500 \mathrm{~g}$ a.i. /ha and profenofos $50 \mathrm{EC} @ 500 \mathrm{~g}$ a.i./ha (market sample) were 83.30 per cent and 80.83 per cent, respectively after one day of spraying. Profenofos 50 EC @ $250 \mathrm{~g}$ a.i./ha was least effective and caused only 68.83 per cent reduction of mite population at the same duration. Similar trend of results were also noticed after 3 and 5 days of treatment. Profenofos 50 EC @ $1000 \mathrm{~g}$ a.i./ha and profenofos 50 EC @ $1000 \mathrm{~g}$ a.i. /ha (market sample) proved to be the most effective having 70.46 per cent and 69.93 per cent reduction of mite eggs, respectively after one day of first spraying and were at par followed by profenofos 50 EC @ $750 \mathrm{~g}$ a.i./ha which resulted 64.40 per cent reduction of eggs. Profenofos 50 EC @ $500 \mathrm{~g}$ a.i./ha (market sample) resulted 63.06 per cent reduction of eggs. The least effective treatments over eggs were profenofos 50 EC @ 500 and $250 \mathrm{~g}$ a.i./ha that resulted 61.16 per cent and 52.10 per cent egg reduction, respectively. Observation on phytotoxicity revealed that all the doses of profenofos $50 \mathrm{EC}$ did not produce any symptoms of phytotoxicity in tea crop after 1, 3, 5, 7 and 10 days of spraying.
\end{abstract}

Keywords: Oligonychus coffeae, Tea, Profenophos, Efficacy, Phytotoxicity

\section{Introduction}

India is the largest producer of tea in the world contributing 27.49 per cent of the world production and 13.09 per cent of the world trade (Muraleedharan, 2006). However, it is estimated that 15-20 per cent of the total crop yield is lost annually from the ravages of pests in spite of the best effort put through routine conventional control measures possible under the commercial conditions (Das, 1960).

During 2010-2011 total Indian production of tea was 9, 66,733 tones, out of which $7,28,526$ tones was produced from North East India. The total tea exported from India in the year 2010 - 2011 was 2, 13,789 tones (Anonymous, 2011). There is a steady increase in the production over the year, which is due to extensive cultivation, improved technology, nutrition and fertility management (Saraswathy et al. 2007), introduction of high yielding clones and longer pruning cycle. These factors, on the other hand, have encouraged biotic stress like pests and diseases which affect the productivity of this crop (Borthakur et al. 2005). More than one thousand species of arthropod pests are known to attack tea crops over the world, though only about 300 species of insect are recorded from India of which 167 species from North East India resulting 11 to 55 per cent annual loss in yield (Das, 1960).

Red spider mite (RSM), Oligonychus coffeae Nietner (Acarina: Tetranychidae) is the most important mite species that attacking tea crop and first reported in 1868 from Assam, India (Watt and Mann, 1903). This pest is widely distributed in India, Bangladesh, Sri Lanka, Taiwan, Burundi, Kenya, Malawi, Uganda and Zimbabwe (Gotoh and Nagata, 2001). Nymphs and adults of RSM lacerate cells, producing minute characteristic reddish brown marks on the upper surface of mature leaves, which turn to red in severe cases, resulting 17-46 per cent crop loss (Das, 1959). High temperatures, dry conditions and the absence of shade are conducive to outbreak of this pest. The optimum temperature for growth and development is $30^{\circ} \mathrm{C}$ (Nagata, 2001), the lower threshold for development is $10^{\circ} \mathrm{C}$ and 23.26 degree days are required to complete the life cycle from egg to egg (Gotoh and Nagata, 2001). Mites inhabiting the upper leaf surface are easily dislodged by heavy rainfall. Red spider mite, $O$. coffeae prefers the middle zone of the bush (30 $\mathrm{cm}$ below the plucking surface) because of optimum temperatures associated with plant shading (Banerjee, 1979). This species occurs throughout the year in Northeast India and its reproductive rate increases with temperature (Das, 1960). Peaks in oviposition were observed at dawn and dusk (Banerjee and Das, 1968).

Chemical control would continue to be the first line of defense against this pest particularly under outbreak situation. Moreover, development of insecticide resistance of pests in tea crop is also anther bottleneck in chemical application. Hence, the programme to evaluate the efficacy and phototoxic effect of profenofos as a new acaricide against red spider mite of tea, $O$. coffeae was undertaken.

\section{Volume 4 Issue 12, December 2015}




\section{International Journal of Science and Research (IJSR)}

ISSN (Online): 2319-7064

Index Copernicus Value (2013): 6.14 | Impact Factor (2014): 5.611

\section{Materials and Methods}

During Kharif, 2013 and 2014 a new molecule of chemical pesticide viz. profenofos $50 \mathrm{EC}$ provided by Horizone Molecules Pvt. Ltd., Hyderabad (India) was evaluated in comparison to the marketed samples of profenofos $50 \mathrm{EC}$ against red spider mite of tea, $O$. coffeae.

\section{Experimental Site:}

The experiment was conducted in the Experimental Garden for Plantation Crops, Assam Agricultural University, Jorhat. The site is situated at $94.13^{\circ} \mathrm{E}$ longitudes, $26^{\circ} 45^{\prime} \mathrm{N}$ latitude and at an altitude of 86.56 meters from the mean sea level. Already established crops of 5 years old, variety TV-23 was selected for the trial. An area of $5 \mathrm{~m} \times 2 \mathrm{~m}$ having 20 plants was taken as individual plot where spacing was $100 \mathrm{~cm} \times 50$ cm. A Randomized Block Design with 3 (three) replication having 7 (Seven) treatment was considered for the experiment.

\section{Data Record:}

Observation on the number of red spider mite, O. coffeae on tea leaves were recorded prior to spray and 1,3,5,7 and 10 days after spraying. Per cent reduction of mite population due to chemical was also calculated for comparison of the treatments.

\section{Spray Schedule}

First spraying of profenofos was done in first week of July, 2013 and 2014 when average population of mite was 30.22 /leaf. Second spraying was done after 10 days of the first spraying in both the seasons.

\section{Statistical Analysis}

The percent reduction of mite population due to acaricidal effect of profenofos were recorded and statistically analyzed by using PASW statistics 18 software.

\section{Results and Discussion}

I. Effect of profenofos $50 \mathrm{EC}$ against red spider mite, Oligonychus coffeae

The results presented in table 1 showed that after $1^{\text {st }}$ spraying all the treatments were found to be significantly superior over control. Profenofos50 EC @ 750,1000 and 1000 (market sample) g a.i. / ha proved to be the most effective treatments which gave 100 per cent reduction of mite population after one day of spraying. This result was in agreed with the findings of Roy et al. (2010) that profenophos was effective in controlling red spider mite in tea. Profenofos 50 EC@ 500 g a.i. /ha resulted 83.30 per cent reduction of mite population, followed by the profenofos50 EC@500 g a.i./ ha (market sample) which resulted 80.83 per cent reduction of mite population and were at par. Profenofos 50 EC @ 250 g a.i. / ha caused only 68.83 per cent reduction of mite population. Similar trend of results were also noticed after 5 days of treatment. Likewise, after seven days of spraying all the treatments resulted 100 per cent reduction of mite population except profenofos50 EC@250 g a.i. / ha which resulted 84.57 per cent reduction of mite population. The lower dose of the chemical i.e. @ $250 \mathrm{~g}$ a.i. / ha could also resulted satisfactory level of 92.44 per cent reduction of mite population but after ten days of spraying (table 1).

The ovicidal action of profenofos $50 \mathrm{EC}$ against $O$. coffeae is presented in Table 2. The result showed that profenofos 50 EC@1000 g a.i. / ha proved to be the most effective treatment which gave 70.46 per cent reduction of eggs after one day of first spraying.

Profenofos 50 EC@1000 g a.i. /ha (market sample) also resulted 69.93 per cent reduction of number of eggs and were at par. This was followed by the profenofos $50 \mathrm{EC}$ @750 g a.i. / ha which resulted 64.40 per cent reduction of eggs. Profenofos 50 EC @ 500 g a.i. / ha (market sample) resulted 63.06 per cent reduction of eggs.

Table 1: Effect of profenofos 50EC against motile stages of Oligonychus coffeae after first spraying, 2013-14

\begin{tabular}{|c|c|c|c|c|c|c|}
\hline \multirow[t]{2}{*}{ Treatment } & \multirow{2}{*}{$\begin{array}{l}\text { Dose } \\
\text { (g a.i./ } \\
\text { ha) }\end{array}$} & \multirow{2}{*}{$\begin{array}{c}\text { Mean no. } \\
\text { of mites } \\
\text { /leaf }\end{array}$} & \multicolumn{4}{|c|}{$\begin{array}{l}\text { Per cent reduction of mite } \\
\text { population }\end{array}$} \\
\hline & & & $1 \mathrm{DAT}$ & $5 \mathrm{DAT}$ & 7 DAT & 10 DAT \\
\hline $\mathrm{T}_{1}$ & 250 & 31.63 & $\begin{array}{c}68.83 \\
(56.04) \\
\end{array}$ & \begin{tabular}{|l|}
79.33 \\
$(62.94)$ \\
\end{tabular} & \begin{tabular}{|l}
84.57 \\
$(66.89)$ \\
\end{tabular} & $\begin{array}{r}92.44 \\
(74.00) \\
\end{array}$ \\
\hline $\mathrm{T}_{2}$ & 500 & 35.30 & $\begin{array}{c}83.30 \\
(65.89)\end{array}$ & \begin{tabular}{|l|}
96.50 \\
$(79.22)$
\end{tabular} & $\begin{array}{l}100 \\
(90)\end{array}$ & $\begin{array}{l}100 \\
(90)\end{array}$ \\
\hline $\mathrm{T}_{3}$ & 750 & 26.64 & $\begin{array}{l}100 \\
(90)\end{array}$ & $\begin{array}{l}100 \\
(90)\end{array}$ & $\begin{array}{l}100 \\
(90)\end{array}$ & $\begin{array}{l}100 \\
(90)\end{array}$ \\
\hline $\mathrm{T}_{4}$ & 1000 & 32.30 & $\begin{array}{l}100 \\
(90) \\
\end{array}$ & $\begin{array}{l}100 \\
(90) \\
\end{array}$ & $\begin{array}{l}100 \\
(90)\end{array}$ & $\begin{array}{l}100 \\
(90)\end{array}$ \\
\hline $\mathrm{T}_{5}$ & 500 & 28.56 & \begin{tabular}{|l|}
80.83 \\
$(64.02)$
\end{tabular} & \begin{tabular}{|l|}
92.45 \\
$(74.11)$
\end{tabular} & $\begin{array}{l}100 \\
(90)\end{array}$ & $\begin{array}{l}100 \\
(90)\end{array}$ \\
\hline $\mathrm{T}_{6}$ & 1000 & 29.67 & $\begin{array}{l}100 \\
(90) \\
\end{array}$ & $\begin{array}{l}100 \\
(90) \\
\end{array}$ & $\begin{array}{l}100 \\
(90)\end{array}$ & $\begin{array}{l}100 \\
(90)\end{array}$ \\
\hline $\mathrm{T}_{7}$ & - & 28.49 & +15.03 & +26.12 & +30.72 & +41.58 \\
\hline $\begin{array}{l}\text { S.Ed }( \pm) \\
\text { CD }(0.05)\end{array}$ & - & NS & $\begin{array}{l}3.14 \\
6.85 \\
\end{array}$ & \begin{tabular}{|c|}
5.02 \\
10.94 \\
\end{tabular} & \begin{tabular}{|l|}
3.76 \\
8.19 \\
\end{tabular} & $\begin{array}{l}2.06 \\
4.49 \\
\end{array}$ \\
\hline
\end{tabular}

The least effective treatments over eggs were profenofos 50 EC@ 500 and $250 \mathrm{~g}$ a.i. / ha that resulted 61.16 per cent and 52.10 per cent egg reduction, respectively (table 2 ).

After five days spraying, profenofos 50 EC @1000 g a.i. / ha proved to be the most effective treatment which gave 95.45 per cent reduction of eggs. On the other hand the market sample of profenofos 50 EC @ 1000 g a.i. /ha (market sample) resulted 81.67 per cent reduction of eggs. This was followed by the profenofos 50 EC @750 g a.i. / ha that resulted 80.22 per cent reduction of eggs. Profenofos 50 EC@ $250 \mathrm{~g}$ a.i. / ha was least effective treatment with 67.33 per cent reduction of eggs after five days of $1^{\text {st }}$ spraying

Likewise, after seven days of spraying profenofos 50 EC @ $1000 \mathrm{~g}$ a.i. / ha maintained its superiority over other treatments in reduction of eggs by 100 per cent where as profenofos50 EC@250 g a.i. / ha was the least effective treatment with 74.56 per cent reduction of eggs. After ten days of spraying all the treatments showed 100 per cent reduction of eggs except profenofos50 EC @250 g a.i./ha that showed 83.67 per cent reduction of eggs (table 2).

\section{Volume 4 Issue 12, December 2015}




\section{International Journal of Science and Research (IJSR) ISSN (Online): 2319-7064}

Index Copernicus Value (2013): 6.14 | Impact Factor (2014): 5.611

Table 2: Effect of profenofos 50EC against eggs of Oligonychus coffeae after first spraying, 2013-14

\begin{tabular}{|c|c|c|c|c|c|c|}
\hline \multirow{2}{*}{ Treatments } & \multirow{2}{*}{$\begin{array}{c}\text { Dose } \\
\text { (g a.i./ ha) }\end{array}$} & $\begin{array}{c}\text { Mean no. of } \\
\text { eggs /leaf }\end{array}$ & \multicolumn{5}{|c|}{ Per cent reduction of eggs } \\
\cline { 3 - 7 } & $\begin{array}{c}\text { (Before } \\
\text { spraying) }\end{array}$ & 1 DAT & 5 DAT & 7 DAT & 10 DAT \\
\hline $\mathrm{T}_{1}$ & 250 & 42.50 & 52.10 & 67.33 & 74.56 & 83.67 \\
& & & $(46.20)$ & $(55.13)$ & $(59.74)$ & $(66.19)$ \\
\hline $\mathrm{T}_{2}$ & 500 & 49.33 & 61.16 & 75.13 & 91.42 & 100 \\
& & & $(51.45)$ & $(60.07)$ & $(72.95)$ & $(90)$ \\
\hline $\mathrm{T}_{3}$ & 750 & 32.66 & 64.40 & 80.22 & 96.40 & 100 \\
& & & $(53.37)$ & $(63.58)$ & $(79.06)$ & $(90)$ \\
\hline $\mathrm{T}_{4}$ & 1000 & 36.33 & 70.46 & 95.45 & 100 & 100 \\
& & & $(57.13)$ & $(77.75)$ & $(90)$ & $(90)$ \\
\hline $\mathrm{T}_{5}$ & 500 & 40.30 & 63.06 & 77.20 & 89.50 & 100 \\
& & & $(52.58)$ & $(61.48)$ & $(71.09)$ & $(90)$ \\
\hline $\mathrm{T}_{6}$ & 1000 & 36.94 & 69.93 & 81.67 & 93.44 & 100 \\
& & & $(56.76)$ & $(64.67)$ & $(75.11)$ & $(90)$ \\
\hline $\mathrm{T}_{7}$ & - & 42.43 & +13.86 & +25.15 & +37.20 & +41.56 \\
\hline $\mathbf{S . E d}( \pm)$ & - & NS & $\mathbf{2 . 9 0}$ & $\mathbf{3 . 1 5}$ & $\mathbf{4 . 5 3}$ & $\mathbf{3 . 5 5}$ \\
$\mathbf{C D ( 0 . 0 5 )}$ & & & $\mathbf{6 . 3 2}$ & $\mathbf{6 . 8 7}$ & $\mathbf{9 . 8 8}$ & $\mathbf{7 . 7 4}$ \\
\hline
\end{tabular}

After second spraying of profenofos 50 EC against red spider mite, $O$. coffeae all the treatments were found to be significantly superior over control. Profenofos 50 EC @ $1000 \mathrm{~g}$ a.i. / ha proved to be the most effective treatment which showed 98.36 per cent reduction of mite population, after one day of second spraying and profenofos 50 EC @ $750 \mathrm{~g}$ a.i. /ha resulted 95.23 per cent reduction of mite population which were at par.

This was followed by the profenofos 50 EC @ $500 \mathrm{~g}$ a.i. / ha that resulted 84.59 per cent reduction of mite population. Profenofos 50 EC @250 g a.i. / ha was least effective treatment with 62.91 per cent reduction of mite population at one day after spraying. Similar results were also obtained after five days of second spraying.

Profenofos50 EC@750 and $1000 \mathrm{~g}$ a.i. / ha proved to be the most effective treatment which give 100 per cent reduction of mite population. Profenofos 50 EC @1000 g a.i. /ha (market sample) resulted 91.54 per cent reduction of mite population. This was followed by profenofos 50 EC @ $500 \mathrm{~g}$ a.i. / ha that resulted 91.42 per cent reduction of mite population which was statistically at par.

Table 3: Effect of profenofos 50EC against motile stages of Oligonychus coffeae after second spraying, 2013-14

\begin{tabular}{|c|c|c|c|c|c|c|}
\hline \multirow{2}{*}{ Treatment } & \multirow{2}{*}{$\begin{array}{c}\text { Dose } \\
(\mathrm{g} \text { a.i./ ha })\end{array}$} & $\begin{array}{c}\text { Mean no. of mites } \\
\text { /leaf }\end{array}$ & \multicolumn{5}{|c|}{ Per cent reduction of mite population } \\
\cline { 3 - 7 } & 250 & 15.30 & 62.91 & 69.5 & 97.40 & 100 \\
& & & $(53.60)$ & $(59.96)$ & $(82.48)$ & $(90)$ \\
\hline $\mathrm{T}_{1}$ & 500 & 18.13 & 84.59 & 91.42 & 100 & 100 \\
& & & $(67.05)$ & $(73.58)$ & $(90)$ & $(90)$ \\
\hline $\mathrm{T}_{2}$ & 750 & 17.56 & 95.23 & 100 & 100 & 100 \\
& & & $(82.59)$ & $(90)$ & $(90)$ & $(90)$ \\
\hline $\mathrm{T}_{3}$ & 1000 & 17.70 & 98.36 & 100 & 100 & 100 \\
& & & $(85.69)$ & $(90)$ & $(90)$ & $(90)$ \\
\hline $\mathrm{T}_{4}$ & 500 & 16.93 & 65.27 & 72.30 & 84.29 & 100 \\
& & & $(53.91)$ & $(58.24)$ & $(66.66)$ & $(90)$ \\
\hline $\mathrm{T}_{5}$ & 1000 & 17.76 & 84.20 & 91.54 & 96.53 & 100 \\
& & & $(66.58)$ & $(73.15)$ & $(79.22)$ & $(90)$ \\
\hline $\mathrm{T}_{6}$ & - & 18.53 & +23.13 & +28.96 & +27.67 & +54.13 \\
\hline $\mathrm{T}_{7}$ & - & $\mathrm{NS}$ & 4.67 & 4.09 & 2013 & - \\
\hline $\mathrm{S} . \mathrm{Ed}( \pm)$ & & & 10.18 & 8.91 & 4.64 & - \\
\hline $\mathrm{C} . \mathrm{D}(0.05)$ & & & & &
\end{tabular}

Profenofos50 EC@250 g a.i. / ha was least effective treatment with 69.50 per cent reduction of mite population at five days after spraying. After seven days of second spraying profenofos50 EC@500 g a.i. / ha (market sample) resulted 84.29 per cent reduction of mite population. All other treatments gave 100 per cent control of mites (table 3 ).

The ovicidal action of profenofos50 EC @ $750 \mathrm{~g}$ a.i. / ha proved to be the most effective treatment which showed
99.35 per cent reduction of eggs, after one day of second spraying. This was followed by profenofos 50 EC @ $500 \mathrm{~g}$ a.i. /ha which resulted 98.80 per cent reduction of eggs and were statistically at par. Profenofos50 EC @250 g a.i./ ha was least effective treatment with 74.36 per cent reduction of eggs. After five days of treatment no viable eggs were noticed. This indicated that the chemical along with the market sample had good ovicidal action (table 4). 


\section{International Journal of Science and Research (IJSR) \\ ISSN (Online): 2319-7064}

Index Copernicus Value (2013): 6.14 | Impact Factor (2014): 5.611

Table 4: Effect of profenofos 50EC against eggs of Oligonychus coffeae after second spraying, 2013-14

\begin{tabular}{|c|c|c|c|c|c|c|}
\hline \multirow[b]{2}{*}{ Treatments } & \multirow{2}{*}{$\begin{array}{c}\text { Dose } \\
\text { (ga.i./ ha) }\end{array}$} & \multirow{2}{*}{$\begin{array}{c}\text { Mean no. of eggs /leaf } \\
\text { (Before spraying) }\end{array}$} & \multicolumn{4}{|c|}{ Per cent reduction of eggs } \\
\hline & & & $1 \mathrm{DAT}$ & $5 \mathrm{DAT}$ & $7 \mathrm{DAT}$ & $10 \mathrm{DAT}$ \\
\hline $\mathrm{T}_{1}$ & 250 & 9.86 & $\begin{array}{c}74.36 \\
(60.24) \\
\end{array}$ & $\begin{array}{c}96.39 \\
(81.75) \\
\end{array}$ & $\begin{array}{r}100 \\
(90) \\
\end{array}$ & $\begin{array}{r}100 \\
(90) \\
\end{array}$ \\
\hline $\mathrm{T}_{2}$ & 500 & 11.16 & $\begin{array}{c}98.80 \\
(84.80)\end{array}$ & $\begin{array}{r}100 \\
(90) \\
\end{array}$ & $\begin{array}{l}100 \\
(90)\end{array}$ & $\begin{array}{l}100 \\
(90)\end{array}$ \\
\hline $\mathrm{T}_{3}$ & 750 & 14.06 & $\begin{array}{c}99.35 \\
(87.29) \\
\end{array}$ & $\begin{array}{r}100 \\
(90) \\
\end{array}$ & $\begin{array}{l}100 \\
(90) \\
\end{array}$ & $\begin{array}{l}100 \\
(90) \\
\end{array}$ \\
\hline $\mathrm{T}_{4}$ & 1000 & 9.43 & $\begin{array}{c}94.41 \\
(78.75)\end{array}$ & $\begin{array}{l}100 \\
(90) \\
\end{array}$ & $\begin{array}{l}100 \\
(90)\end{array}$ & $\begin{array}{l}100 \\
(90)\end{array}$ \\
\hline $\mathrm{T}_{5}$ & 500 & 10.06 & $\begin{array}{c}98.28 \\
(85.60) \\
\end{array}$ & $\begin{array}{r}100 \\
(90) \\
\end{array}$ & $\begin{array}{r}100 \\
(90) \\
\end{array}$ & $\begin{array}{r}100 \\
(90) \\
\end{array}$ \\
\hline $\mathrm{T}_{6}$ & 1000 & 12.70 & $\begin{array}{c}88.37 \\
(70.09) \\
\end{array}$ & $\begin{array}{c}95.00 \\
(77.08) \\
\end{array}$ & $\begin{array}{l}100 \\
(90) \\
\end{array}$ & $\begin{array}{l}100 \\
(90) \\
\end{array}$ \\
\hline $\mathrm{T}_{7}$ & - & 10.06 & +24.76 & +39.97 & +49.41 & +57.08 \\
\hline $\begin{array}{c}\text { S. Ed }( \pm) \\
\text { C.D }(0.05)\end{array}$ & - & NS & $\begin{array}{l}2.82 \\
6.15 \\
\end{array}$ & $\begin{array}{l}1.81 \\
3.94 \\
\end{array}$ & $\begin{array}{l}- \\
-\end{array}$ & - \\
\hline
\end{tabular}

Tables 1-4: Data are pooled mean of two season trials,

$\mathrm{DAT}=$ Days After Treatment, NS= Not significant,

' + ' indicates per cent increase, Figure in parentheses are angular transformed value

\section{Evaluation of Phytotoxicity of Profenofos 50 EC on tea:}

Observation for phytotoxicity was made in all the treatments of evaluating the efficacy of profenofos $50 \mathrm{EC}$ at $1,3,5,7$ and 10 days after spraying. The observations on specific parameters like chlorsis, necrosis, wilting, scorching, hyponasty and epinasty etc. were made in 0-10 scale scoring. The study revealed that no such symptoms were noticed on the sprayed tea crop during the period of investigation.

\section{References}

[1] Anonymous, 57 ${ }^{\text {th }}$ Annual Report, Tea board of India: Tea Board website: http:// teaboard.gov.in/, 2011.

[2] B. Banerjee, G. M. Das, The effect of light on oviposition rhythm of the tea red spider mite (Oligonychus coffeae ), Bulletin of. Entomological Research, 59 (2), pp. 371-376, 1968.

[3] B. Banerjee, Intra-tree variation in the distribution of the tea red spider mite, Oligonychus coffeae (Nietner), Acarologia, 21, pp. 216-220, 1979.

[4] G. Watt, and H. N. Mann, The Pests and Blights of the Tea Plant, Calcutta: Gov. Printing Press, pp. 429, 1903.

[5] G.M. Das, Bionomics of tea red spider Oligonychus coffeae (Nietner), Bulletin of Entomological Research, 50, pp. 265-275, 1959.

[6] G.M. Das, Occurrence of red spider Oligonychus coffeae (Nietner) on tea in North East India in relation to pruning and defoliation. Bulletin of Entomological Research, 51, pp. 415-426, 1960.

[7] M. Borthakur, A. Rahman, M. Sarmah and G. Gurusubramanian, Predators of phytophagous mites of tea (Camellia sinensis) in North East India, In Proceedings of 2005 International Symposium on Innovation in Tea Science and Sustainable Development in Tea Industry, Hangzhou, China, 11-15 November, pp. 749-755, 2005.
[8] N. Muraleedharan, Sustainable cultivation of tea. In Handbook of Tea Culture. Valparai, India: UPASI Tea Research Foundation, 2006.

[9] R Saraswathy, S. Suganya and P. Singaram, Environmental impact of nitrogen fertilization in tea eco system, Journal of Environmental Biology, 28, pp. 779788, 2007.

[10] S.Roy, A. Mukhopadhyay and G. Gurusubramanian, Relative susceptibility of Tea mosquito bug, Helopeltis theivora waterhouse and Red spider mite, Oligonychus coffeae Nietner eggs to commonly used pesticides, Journal of Plant Protection Research, 50 (3). 2010.

[11]T. Gotoh, and T. Nagata, Development and reproduction of Oligonychus coffeae (Acarina: Tetranychidae) on tea. International Journal of Acarology, 27, pp. 293-98, 2001.

[12] W.S. Abbott, A method computing the effectiveness of an insecticide, Journal of Economic Entomology, 18, pp. 265-267, 1925.

\section{Author Profile}

Dr. S. Rahman is working as Senior Scientist of AINP on Agricultural Acarology, Department of Entomology, Assam Agricultural University, Jorhat, India. $\mathrm{He}$ has guided several numbers of $\mathrm{M}$. Sc. and $\mathrm{Ph}$. D. students and handled several externally funded projects during his service period. Dr. Rahman has ample number of publications in several National and International reputed journals. 